\title{
Arte outdoor como zona autônoma temporária: plataformas exibitivas da arte urbana e discursos piratas
}

\section{Billboard art as a temporary autonomous zone: urban art's exhibitive platforms and pirate speeches}

Rafael Luiz Zen ${ }^{1}$ Célia Maria Antonacci Ramos ${ }^{2}$ 


\section{Resumo}

A publicidade é um conjunto de práticas que aliam técnicas discursivas a uma construção simbólica para o desenvolvimento de marcas e utiliza os meios de comunicação para a venda de seus objetos. A partir da análise de obras de Félix González-Torres, Barbara Kruger, coletivo PORO e coletivo ETC, perguntou-se: pode a arte contemporânea possibilitar um contra-ataque aos discursos normativos, propondo a ocupação de outdoors como plataforma exibitiva de conceitos piratas? A partir dessa indagação inicial, objetivou-se correlacionar o outdoor como ferramenta da retórica capitalista e sua ocupação como plataforma exibitiva da arte e de seus discursos piratas. Percebendo a arte urbana como polemizadora de discursos nas visualidades urbanas, conclui-se que a arte outdoor constrói espaços-entre porque são polêmicos tanto quanto efêmeros, constituindo uma poética possível ao espaço urbanizado da cidade, uma tentativa de voz em meio ao excesso de vozes.

Palavras-chave: Zona autônoma temporária. Arte outdoor. Terrorismo poético. Arte urbana. Linguagens do consumo.

\section{Abstract}

Advertising stands for a group of practices that ally discursive techniques with symbolic constructions to brand development and uses media to sell its objects. From the work of art analysis of Félix Gonzalez-Torres, Barbara Kruger, PORO colective e ETC colective, it is asked: can contemporary art enable a counterattack to normative speeches, proposing the occupation of billboards as an exhibitive platform for pirate concepts? From this initial question, this arcticle's main goal is to correlate the billboard media as a tool of capitalist rhetoric and its occupation as an exhibitive platform for pirate speeches. Realizing urban art as a polemizer of speeches on urban iconography, it is concluded that billboard art builds spaces-between because are as polemic as ephemeral, making possible poetics to the city's urbanized space, a voice attempt within an excess of urban voices.

Keywords: Temporary autonomous zone. Billboard art. Poetic terrorism. Urban art. Consumerism languages.

ISSN: 2175-2346

${ }^{1}$ rafikizen@hotmail.com

${ }^{2}$ celia.antonacci@gmail.com 


\section{Introdução (ou, Por uma esfera de livres discursos)}

O outdoor, um dos meios de comunicação de massa mais imponentes das visualidades urbanas, pode ser compreendido como um mural dos desejos para o homem-consumo. É também nele - mas não somente, haja vista que a publicidade opera sob a ótica da comunicação integrada que reúne, além de uma gama de meios, atividades diversificadas da área da comunicação, como técnicas de marketing e relações públicas - que somos tomados por discursos visuais e verbais que alimentam a retórica do desejo dentro do contexto urbano.

É pela visualidade publicitária que toma a cidade em telas, painéis, paredes, vitrines, lugares e pessoas que se estabelece o poder do consumo. Indoor ou outdoor, é por meio desse incessante diálogo que normalizamos - em um sentido de monopolizar a cultura para obter dessa massa homogênea um discurso único e coeso - o caráter consumidor da vida. Inserindo camadas de desejos latentes no universo público e particular do convívio social, acostuma-se o ciclo infinito, em uma imagem remetente ao mito grego do ourobouros, a cobra que mastiga o próprio rabo na tentativa de consumir-se um pouco mais a cada vez.

Tornar algo público significa fazer com que esse mesmo algo participe da vida compartilhada, fazer com que se estabeleça como comum entre todos. Analisado por essa ótica, o outdoor surge como aquele que abrange o espaço além da porta, que sai do espaço do lar para ser compartilhado com outrem. É, portanto, um dos oráculos dessa nova ágora, um dos agentes simbólicos do discurso vigente, um meio narrativo que propõe apresentar e convencer sobre a retórica do consumo.

É no outdoor, e aqui posso abranger como outdoor as ferramentas urbanas de comunicação publicitária - empenas, cartazes, panfletos, telões de LED e LCD, back e frontlights, e outras inúmeras novidades criadas para sustentar a lógica do discurso de forma cada vez maior e mais atraente - que se socializam os desejos partilhados. Dessa forma, dentro e fora se tornam uma manifestação única e aderente das necessidades do mercado neoliberal.

Eis a investida publicitária máxima, fazer com que os estímulos sejam incessantes, múltiplos e que ocorram nas mais diversas plataformas que conversam com o viver privado e político. Propagandas não são apenas difusores de produtos e serviços, mas agregam a esse fator informativo uma alocução de venda real e simbólica.

Travestem-se de piada, de belas imagens, de sonhos possíveis de serem concretizados em tantas vezes sem juros. São pedaços de realização negociáveis a taxas baixas e parcelamentos infinitos. Se é na rua que ocorre o tipo de socialização que se propõe investigar, a proliferação do consumo como prática cultural alienante, então o outdoor como sistema propagador também é locutor dessa lógica.

Compreendendo esse sistema de signos oriundos do tempo contemporâneo, questiona-se como se comportam as produções artísticas que dialogam os conceitos desse regime imposto para a sociedade hiperconsumidora, principalmente como constituem o outdoor como uma zona autônoma temporária que dialoga contradiscursos a partir da ótica dos terrorismos poéticos. Problematizam-se, então, as linguagens poéticas e como podem discutir as políticas sociais e afetivas propostas pela publicidade. 
Pergunta-se: pode a arte contemporânea possibilitar um contra-ataque aos discursos normativos propondo a ocupação de outdoors como plataforma exibitiva de conceitos piratas? Para tanto, proponho a análise de obras de quatro artistas: o mexicano Félix González-Torres, a americana Barbara Kruger, o coletivo mineiro Poro e o coletivo catarinense ETC.

A partir da triangulação entre os conceitos teóricos abordados, as obras de arte pesquisadas e os discursos apontados como persuasivos e midiáticos, busca-se realizar o objetivo principal dessa pesquisa - correlacionar o outdoor como veículo midiático e ferramenta da retórica capitalista na sua ocupação como plataforma exibitiva da arte e de seus discursos piratas.

Para tanto, possui como objetivos secundários analisar as teorias de Hakim Bey acerca dos termos "zona autônoma temporária" e "terrorismo poético", além de demonstrar caminhos possíveis para a arte urbana como ferramenta contestadora aos discursos vigentes.

Metodologicamente, o estudo pressupõe as etapas: pesquisa bibliográfica e correlações teóricas que permitam correlacionar o outdoor como veículo midiático e ferramenta da retórica capitalista na sua ocupação como plataforma exibitiva da arte e de seus discursos piratas, principalmente nos textos de Pena e Wan-Dall Junior (2012), Toscani (2005), Coletivo Poro (2016), Bey (2003) e Thibaud (2012).

Além disso, para que fosse possível a operacionalização dos objetivos específicos, foram adotados os procedimentos metodológicos: pesquisa e correlação bibliográfica em Bey (2003 e s/d) para analisar os termos "zona autônoma temporária" e "terrorismo poético", bem como estudos de caso a partir das obras de Félix González-Torres, Barbara Kruger, Coletivo Poro e Coletivo ETC, pautando suas análises a partir dos pressupostos teóricos abordados, para demonstrar caminhos possíveis para a arte urbana como ferramenta contestadora aos discursos vigentes.

Através da formulação dessa pesquisa, busca-se identificar relações entre o regime discursivo publicitário e as produções de narrativas subjetivas mediante manipulações poéticas de linguagem concernentes a esse tipo de cultura contemporânea.

Percebendo modos de inserir as artes visuais, principalmente a arte urbana, como polemizadora desses discursos nas visualidades da cidade, especificamente no meio outdoor, a presente temática transita entre as questões da identidade na sociedade do consumo, investigando a compreensão do pertencimento pelas poéticas visuais a partir da compreensão das linguagens midiáticas como objetos da construção cultural.

\section{Plataformas exibitivas para diálogos urbanos}

Sobre a prática cotidiana da cultura, Hall (1997) afirma que os significados culturais não estão apenas na cabeça do público, pois têm efeitos reais e regulam trocas sociais. A linguagem, seu agente atribuidor, configura um sistema representativo que faz com que os objetos, pessoas e eventos só adquiram valor mediante uma projeção mental que thes atribui um determinado sentido sociocultural. Conviver e transitar entre objetos são, portanto, não somente fenômenos do plano do pensamento, mas um tipo de regulação das relações. 
A representação só pode ser analisada de maneira satisfatória quando no exercício concreto da leitura dos objetos e a que eles se referem. Para uma compreensão completa do objeto cultural, seria necessária a análise dos verdadeiros sinais, símbolos, figuras, imagens, narrativas, palavras e sons - as formas materiais - onde circula seu significado simbólico.

A configuração social da política pode ser pautada pela manifestação do seu discurso. Por discurso, compreende-se a tomada da linguagem em detrimento do emissor, pois aquele que fala sempre produz um tipo de poder sobre o que ouve.

Conforme Hall (1997) afirma no texto The Work of Representation (primeiro capítulo do livro Representation: cultural representations and signifying practices, de 1997, a partir de tradução livre do autor do artigo), a linguagem sustenta o diálogo entre indivíduos porque opera por meio de um sistema representacional de signos - palavras, sons, escrita, imagens produzidas eletronicamente, objetos - e por meio deles configuramos nossos pensamentos, conceitos, ideias e sentimentos.

É claro, portanto, como a configuração dos estímulos de consumo pode programar a vida permeada por signos espetaculares. Constituindo uma rede colossal, e ao mesmo tempo camuflada, de persuasões programadas, a representação capitalista do estilo de vida contemporâneo torna-se a linguagem central do processo social de pertencimento.

Esses valores compartilhados, no entanto, não dizem respeito apenas à combinação de estímulos - novelas, revistas, pinturas, gibis, carros de som, filmes, canções, romances, programas de auditório, outdoors, letreiros - mas à combinação de processos dentro de um mesmo sistema. Desse sistema, afirma-se que se preocupa em produzir e compartilhar seus significados - dar e receber estímulos - entre os membros de uma sociedade ou de um grupo.

Assim, dizer que duas pessoas pertencem à mesma cultura é dizer que interpretam o mundo, grosseiramente, do mesmo modo, ou seja, que conseguem expressar seus pensamentos, sensações e desejos de forma funcional, ou seja, a partir da compreensão por ambas as partes da realidade embutida nesses discursos.

Sabendo-se que em qualquer sociedade há uma ampla gama de significados sobre um mesmo tópico - e mais de uma maneira de representá-lo, também se afirma que tratar do ambiente cultural urbano é dizer respeito às sensações, conexões e emoções sobre esses tópicos, ou seja, as respostas humanas pautadas em relação aos estímulos simbólicos.

Transpondo esse conceito para o foco dessa pesquisa - as plataformas exibitivas da publicidade - dizer que existe uma cultura do consumo é afirmar que exista um sistema discursivo que alie sensações e emoções aos processos de promoção das marcas.

Afirma-se então que a sociedade contemporânea perpetua a cultura iconográfica, moldando aspectos do ser e do parecer enviesados por hábitos que se fantasiam de valores instransponíveis ao conviver urbano.

$\mathrm{Na}$ cidade, a publicidade atrai, convence, satisfaz desejos que ela mesma implanta, abastece as casas, cria alegorias, branda seus próprios fogos, cessa seus próprios mandamentos. Constrói ambientes propícios para reestabelecer seu fluxo. Entre vitrines, outdoors, placas de LCD e LED, luminosos, cartazes, panfletos, aparelhos 
televisores, estampas em camisetas, carros de som, aparelhos celulares e aplicativos móveis, ela também dita maneiras de vivenciar e compreender o mundo. Estabelece-se, então, o ambiente ideal para novos e incessantes discursos.

Toscani (2005) compreende a realidade atual como um colonialismo cultural das marcas. Ao vender não apenas produtos, mas modelos de vida - sistemas sociais homogeneizadores - assume-se uma indústria cujo foco é a conquista. Quando se insere na realidade dos países de terceiro mundo, oferece modelos da existência ocidental feliz, com flocos de milho pela manhã e hambúrgueres ao meio-dia.

Para isso, instaura imagens à disposição do discurso - subliminares, eróticos, imagens da juventude impossível, da opulência da saúde, da felicidade plástica. Substitui gostos enraizados por produtos genéricos de qualidade duvidosa. Destrói as outras maneiras de pensar e viver pela onipresença do capital. Ilude públicos-alvo de todas as faixas etárias pela necessidade do lucro.

Sobre as práticas de pedagogia cultural, o autor concorda que ela raramente ensina alguma coisa, sendo somente um incessante reprodutor infinito destinado ao giro monetário - por isso, cada um de nós pagaria uma taxa, incluída no preço do produto a ser ofertado, que compraria mais e mais estímulos. Por isso, seu trabalho frente à marca italiana Benetton gerou tanta repercussão. Conforme apresentado abaixo, utilizou imagens polêmicas para gerar discussões sociais mediante a publicidade.

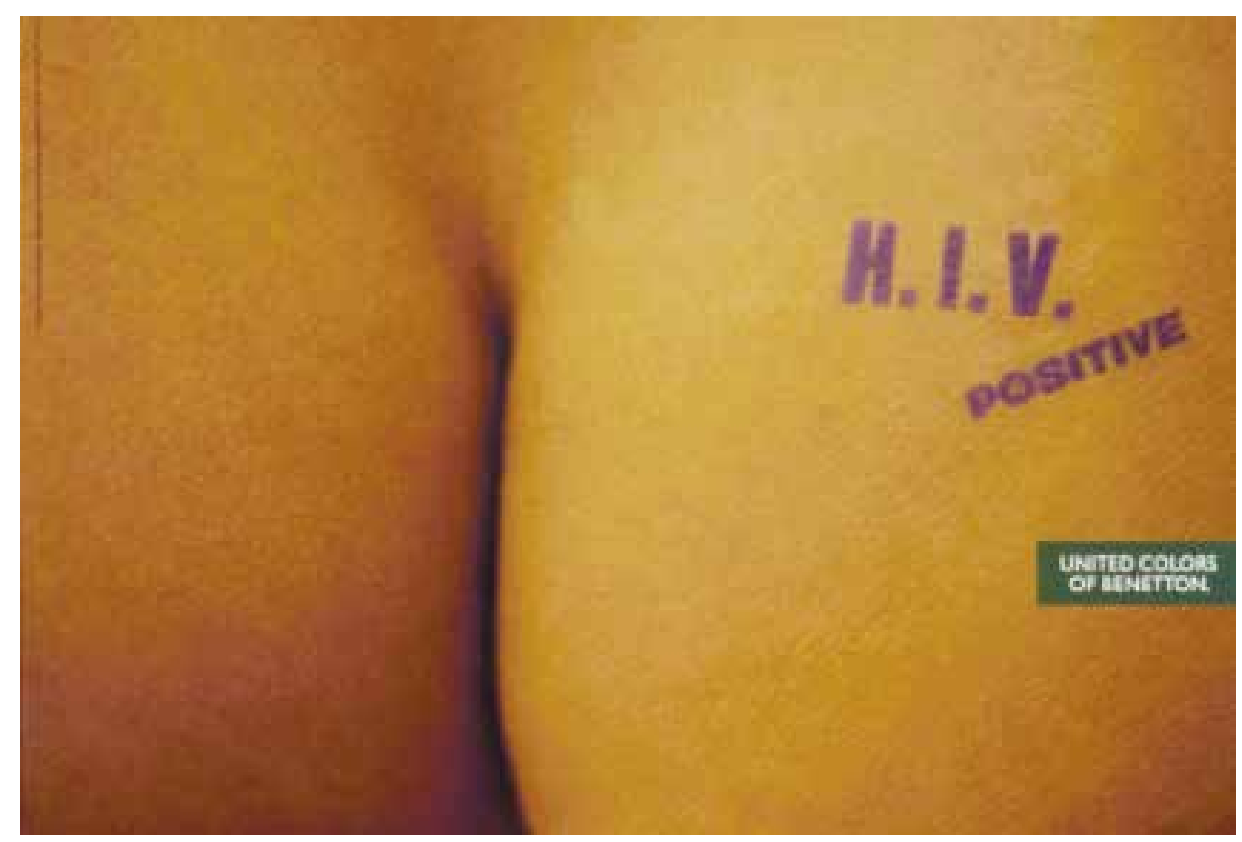

Fig. 01 - Campanha da marca Benetton por Oliviero Toscani Fonte: TOSCANI, 2005

Socialmente, não existiria uma história oficial de provocação. Isso porque é tarefa do marketing amenizar os conflitos e esconder os problemas. A partir dessa realidade, o fotógrafo fez história frente à Benetton por apresentar campanhas cujas imagens pretendiam o choque e reflexões diretas a temas como religião, preconceito, AIDS, guerra, acidentes ambientais e igualdade de gênero.

Em sua visão, há cada vez mais pessoas dispostas a refletir sobre os problemas sociais que inquietam a vida contemporânea, sem por isto deixar de comprar o fru- 
to da engrenagem do capital. Seus outdoors são uma provocação clara ao que, de acordo com sua visão, deveria ser uma norma do sistema: utilizar a força dos meios já existentes para práticas educativas e de chamariz a discursos contraculturais.

Para Toscani (2005), parece legítimo que uma indústria utilize a verba destinada a convencer alguém de alguma coisa que é facilmente constatada - como no caso da qualidade de um pulôver - para chamar a atenção para realidades que nosso olhar condicionado nega ou refuta.

No âmbito do planejamento publicitário, a Benetton renova nos anos 1990 seus aparatos mercadológicos, colocando em crise pelo menos suas características mais óbvias e obsoletas. Assim, seu significado e valor estético ultrapassam os círculos fechados das agências, das revistas especializadas e entram no cotidiano das pessoas que se apaixonam, discutem e aprendem essa dialética da mudança, possibilitando que o fotógrafo utilize os campos da publicidade para a prática da discussão social. Como afirma McCarthy (2010):

A arte novamente transformou-se em algo mudo, de certa forma. Está tudo tão elitizado, e voltado ao capital, e rarefeito. Mas há a ideia de que a prática artística pode ter uma vibração diferente em seu entorno, que ela pode responder à altura. A ideia de que arte pode ser ativa, ao invés de ser um agente passivo na sociedade. (MCCARTY in WALLESTON, 2010)

A ideia acima reflete uma cena comum na realidade atual, o domínio da cultura liquefeita do consumo. Quem afirma é a artista e ativista Marlene McCarty, membro do Gran Fury ${ }^{1}$, em resposta à pergunta: arte basta? Pela sua visão, pode bastar para incitar atmosferas de discussão e diálogo.

A ideia da prática artística como vibração das discussões sociais não é uma pauta recente. Fruto do século XX, mais precisamente entre os anos 1980-1990, a arte ativista prevê concatenações entre arte, ativismo político, discursos contraculturais e produção coletiva.

Entre intervenções urbanas, circuitos alternativos de produção e distribuição, projetos com comunidades e colaborações com movimentos sociais, esse tipo de obra - que coloca até o conceito de obra à prova - impacta o sistema de arte e consegue apoio e validação de museus, galerias e mostras.

A seguir, analisa-se o trabalho de alguns artistas que utilizam os princípios da arte ativismo, cujos conteúdos discutem o papel da publicidade e seu conjunto de ideologias que convidam milhões de consumidores por dia à ação. A escolha desse recorte deu-se para dialogar com as possibilidades de contra ataque ao sistema publicitário vigente, principalmente nas visualidades urbanas e/ou no meio outdoor.

\subsection{Plataformas exibitivas da arte urbana: o outdoor como ferramenta do discurso social}

O artista Felix González-Torres é conhecido por suas instalações minimalistas, pelo uso de materiais diversos como lâmpadas, pilhas de papel, balas e relógios, e pelo uso da arte como ferramenta para o ativismo social, inclusive para a causa gay.

1 Grupo de artistas e designers que produzia trabalhos relacionados principalmente à AIDS na década de 1980, utilizando para isso a lógica do discurso publicitário, que mais recentemente participou do movimento Occupy Wall Street. 
Também utilizou com notoriedade a arte-outdoor, tendo criado obras individualmente e como membro dos coletivos Gran Fury e do Group Material².

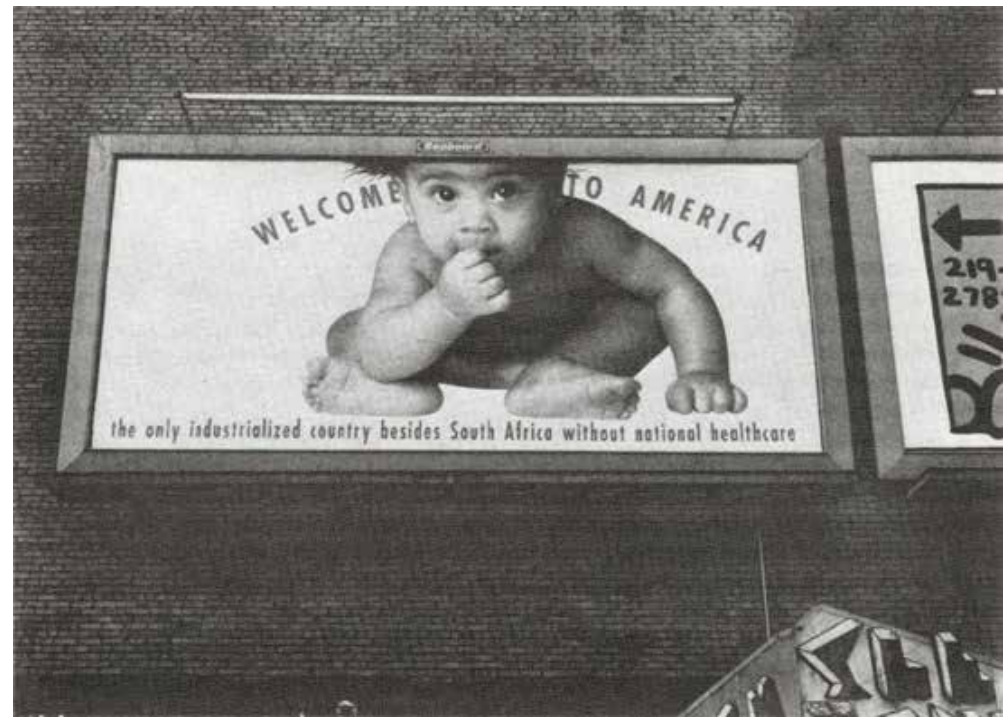

Fig. 02 - Bem-vindo à América, o único país industrializado além da África do Sul, sem plano nacional de saúde (1989), arte-outdoor do coletivo Gran Fury

Fonte: Banco de Imagens do Google ${ }^{3}$.

O coletivo também ficou reconhecido por uma performance de 1988 , onde homens engravatados deixaram cair sacos de lixo cheios de notas falsas de dólares com mensagens de conscientização sobre a crise da AIDS nos anos 1980.

Com mensagens como "Homens brancos heterossexuais não podem pegar AIDS, não conte com isso", "Foda-se sua exploração. Pessoas estão morrendo quanto você brinca de fazer negócios" e "POR QUE ESTAMOS AQUI? Porque sua negligência maldita mata", as notas emergiam uma crítica em resposta à monopolização da distribuição de remédios para AIDS pela indústria farmacêutica, fazendo com que fosse impossível conseguir esse tipo de medicamente na forma genérica.

Ambas as obras - Wall Street Money (1988) e Welcome to America (1989) - são exemplos concisos da maneira como o Gran Fury utilizava métodos da publicidade para levar suas mensagens à população. Fosse através de cartazes, pôsteres, flyers ou outdoors, o intuito do coletivo era criar seus próprios slogans de conscientização política.

2 Coletivo que produziu obras em suportes variados, abordando temas artísticos, sociais e políticos também nos anos 1980.

3 Disponível em: http://36.media.tumblr.com/a7610c687ccdab1e20d349026b994c99/tumblr_mqyr4vGCyB1sx2ksvo2_1280.jpg. Acessado em 16 de fevereiro de 2018. 


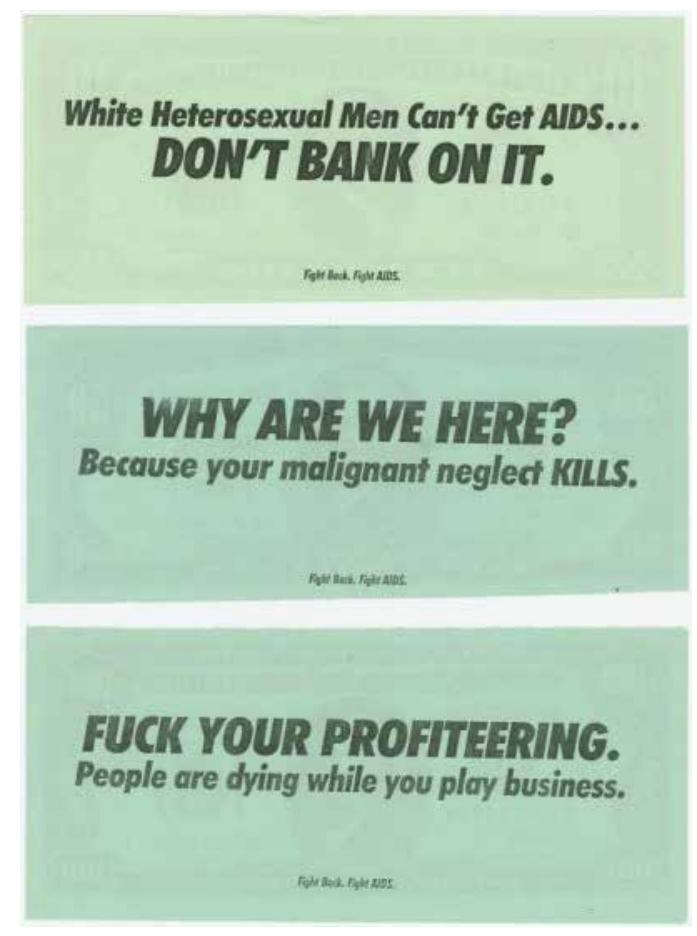

Fig. 03 - Wall Street Money, do coletivo Gran Fury Fonte: Banco de Imagens do Google 4 .

Outro trabalho do Gran Fury, talvez seu projeto mais polêmico, é a apropriação de espaços urbanos destinados à publicidade para a mensagem "Beijar não mata: ganância e indiferença matam". Expostos na forma de outdoors e busdoors, a mensagem tinha formato claramente publicitário e chocava na medida em que se confundia com tantas outras mensagens persuasivas destinadas ao consumo. $\mathrm{Na}$ arte, heterossexuais e homossexuais beijavam-se, numa crítica à forma como portadores do vírus da AIDS eram enxergados na sociedade americana da época.

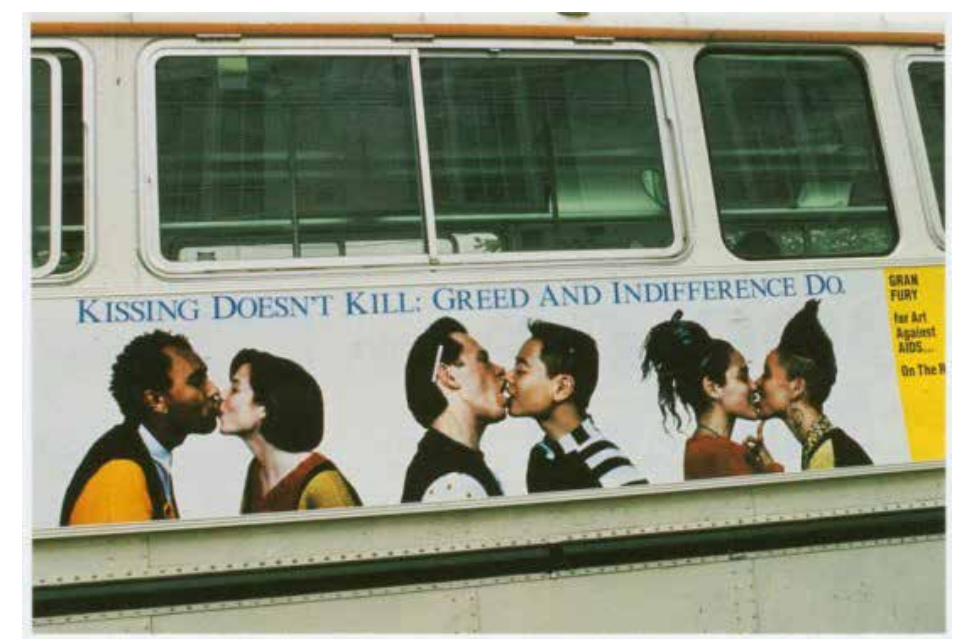

Fig. 04 - Kissing doesn't kill, arte-outdoor e arte-busdoor do coletivo Gran Fury Fonte: Banco de Imagens do Google 5 .

\footnotetext{
4 Disponivel em: https://encrypted-tbn2.gstatic.com/images?q=tbn:ANd9GcRcLuQqMcL D7q_1Clcy6hYOnslvOvYuM1ZQvN3YflvefV6uXcV0CA. Acessado em 16 de fevereiro de 2018.

5 Disponivel em: http://focusfeaturesmedia.com/uploads/image/mediafile/1385413290-2e2efbd4fa6e33e2c9f40c6586f03735/x950.jpg. Acessado em 16 de fevereiro de 2018.
} 
Assim, podemos perceber que a arte-outdoor em muito se relaciona com o conceito de ativismo político através de iniciativas efêmeras. Um espaço de discussões da contracultura que se insere aos olhos da massa para provocar pensamentos não discutidos ou abafados pela população.

Felix González-Torres também utilizou essa prática em seu trabalho autoral. Transformou o outdoor em um espaço coletivo para discussões de foro íntimo. Focado nas discussões acerca da AIDS (o parceiro do artista veio a falecer por complicações oriundas da doença), ele chamou a atenção do público na cidade de Nova lorque por estampar no espaço urbano (do mesmo jeito que a publicidade escancara seus produtos e sua lógica do consumo) uma reflexão sobre a invisibilidade dos pacientes da doença.

O artista cubano produz em seus polêmicos trabalhos uma atmosfera de discussão social que extrapola o universo da arte e reverbera nas políticas públicas e no sistema de saúde americano. Seus temas complexos (amor, perda, separação, morte) utilizam objetos mundanos para convidar o observador a ser um membro ativo das discussões nacionais. Seja da propagação da AIDS (que o próprio artista contraiu na década de 1980) ou do ativismo social e das condições do sistema nacional de saúde, suas obras são chamadas à discussão.

Compreendendo a arte como um agente crucial para a mudança do status quo, o engajamento social de González-Torres é proposto de forma íntima, quase imperceptível aos olhos dos passantes apressados. Um dos trabalhos mais reconhecidos do artista, "Sem título - é só uma questão de tempo" de 1991, foi uma série de outdoors instalados em vinte e quatro locais de Nova lorque.

Apresentando uma foto monocromática de uma cama desocupada (feita da própria cama vazia do artista após a morte de seu parceiro Ross Laycock), a obra é uma tentativa mínima e, ao mesmo tempo, grandiosa sobre a dificuldade de chamar a atenção para as questões do tratamento da AIDS em um país insistente em discriminar a doença.

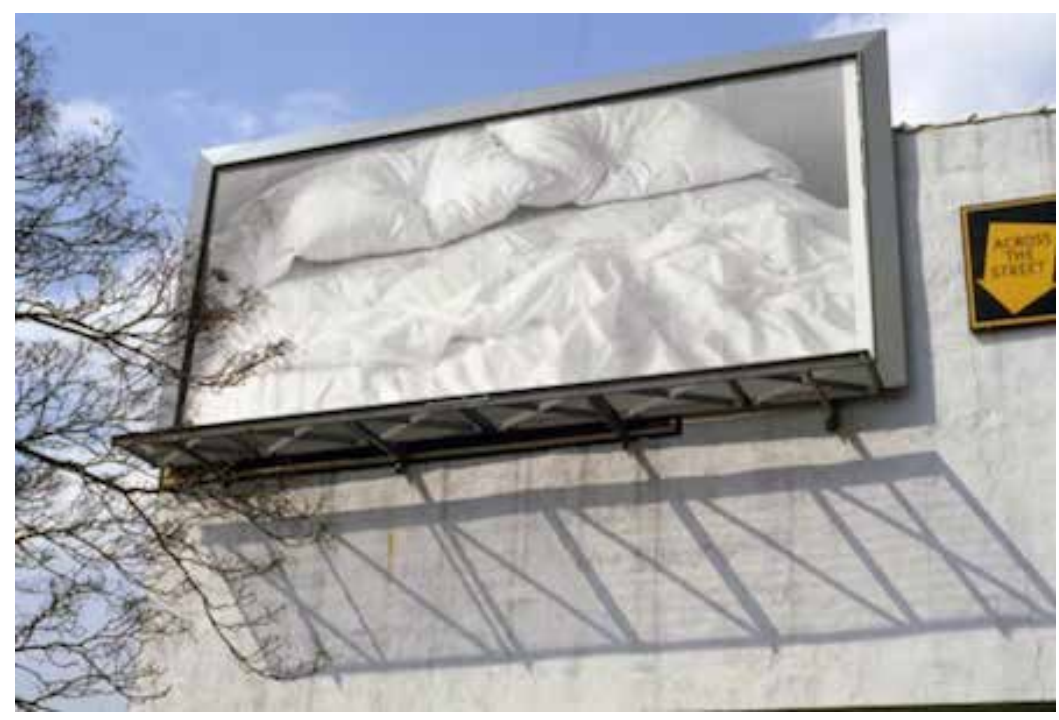

Fig. 05 - Sem título - é só uma questão de tempo (1991), de Felix Gonzalez-Torres Fonte: Banco de Imagens do Google ${ }^{6}$.

6 Disponível em: https://ka-perseus-images.s3.amazonaws.com/ea6d523b2a1a3fb6e fdbcb1574fc4156f07c5ed0.jpg. Acessado em 16 de fevereiro de 2018. 
Perguntado sobre o público para o qual a obra teria sido feita, González-Torres disse enfático: o público era Ross, o resto das pessoas estava apenas passando por ela. Os dois travesseiros dispostos em uma cama por fazer é um esforço político- poético no sentido de ocupar a cidade com sentimentos privados, na tentativa de sensibilizar o pensamento social estagnado.

$\mathrm{Na}$ época (se é que hoje em dia pode-se afirmar que o pensamento foi alterado), a cama desfeita de um casal homossexual soropositivo estampado no mesmo espaço das propagandas alienadoras mesclava as esferas pública e privada em um contexto discriminatório e homofóbico, convidando o observador ao pensamento imersivo. Comentou González-Torres, em entrevista a Hans Ulrich Obrist:

A ideia inicial, portanto, era não expor nada no museu, não ter nenhum painel ali dentro, apenas os livretos que diziam às pessoas onde encontrar as peças nas ruas. Mas, é claro, houve alguns problemas em relação a isso no museu; é quase como se eles precisassem ver o valor monetário, sabe? Sendo assim, instalei uma peça ali dentro, e fico feliz agora de ter feito isso, e expus 24 outdoors com a mesma imagem em 24 pontos da cidade. (GONZÁLEZ-TORRES in OBRIST, 2011, p. 118)

Outra obra que utiliza o espaço público para a reflexão é "Palm Reading" (Leitura de Mão, de 1992). Outra fotografia em preto e branco, retratando a palma de uma mão, em larga escala, que ocupou a fachada de prédios e outdoors pela cidade. Para González-Torres, a obra indagava: o que a mão significa? Auxílio? Ajuda? Bondade? Boas-vindas?

\subsection{Críticas à monopolização da cultura: do capital ao indivíduo}

Mais conhecida por articular a crítica às relações sociais, ao estilo de vida e aos estereótipos de dominação ao modo de operação da lógica publicitária dentro do universo artístico, a americana Barbara Kruger transpõe o discurso mercadológico para a linguagem artística quando utiliza os próprios meios de comunicação tradicionalmente ligados à publicidade para a operacionalização da crítica.

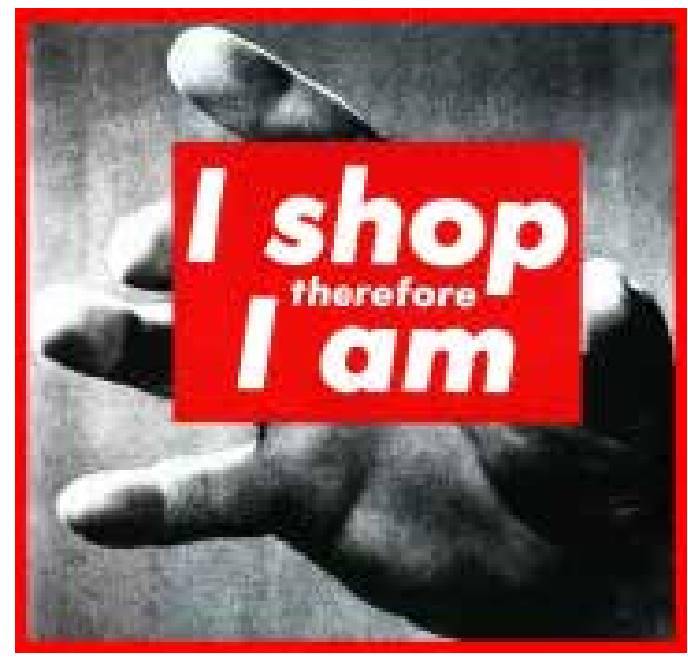

Fig. 06 - Eu compro portanto eu sou Fonte: Site Art Net $^{7}$

7 Disponivel em: http://www.artnet.com/artists/barbara-kruger/untitled-i-shop-therefore-i-am-aXB19HyZ2RQTie638E6pBQ2. Acessado em 16 de fevereiro de 2018. 
A partir de 1979, a artista passa a utilizar mídias diversas para construir sua linguagem artística, com traços característicos que imprimem às obras sua assinatura principal: o flerte com os discursos do consumo. Começa, então, a trabalhar com fotos, palavras e textos que fazem alusão ao vocabulário da publicidade, subvertendo-o e utilizando-o como linguagem artística, focando em temas sociais, como a violência, a saúde pública e a discriminação. Kruger constrói um universo pictórico que se apropria de imagens antigas (em preto e branco) para sobrepor nelas textos acusatórios.

Deste universo, imergem slogans como: "Eu compro portanto eu sou", "Dinheiro pode comprar amor", "Quem ela pensa que é? Está na hora das mulheres pararem de ser politicamente agressivas", "Essa obra prima é só um papel que desempenhamos", "Amor à venda", "Quando eu ouço a palavra cultura eu tiro meu talão de cheques", entre inúmeros outros.

Além das imagens fortes que evoca, Kruger utiliza frases de efeito que redimensionam o caráter de apropriação de suas obras. Não somente pelo valor textual, o aspecto de sua arte confere um aspecto de design de revista, remetendo ao período do mercado publicitário-editorial quando nasce a linguagem gráfico-artística (LUCIE-SMITH, 2006).

Ao promover o estranhamento ao transpor a linguagem publicitária para o meio artístico, Kruger:

"[...] não atua, simplesmente, através de lugares institucionalizados como museus e galerias. Ao contrário, ela também explora a dinâmica e as possibilidades que as ruas de grandes cidade oferecem para potencializar o alcance de suas idéias, figuras e ideais. Assim, sua obra pode ser apreciada em outdoors, cartazes, fachadas de ônibus, bolsas, sacolas, camisetas, dentre uma diversidade de suportes privilegiados da publicidade" (SILVA, VANESSA R. de L., 2006, p.3)

A artista aplica suas obras no contexto urbano e posiciona suas obras em lugares tradicionalmente ocupados pela comunicação publicitária. Causa, assim, estranhamento no observador por construir a partir disso uma oposição: o espectador estranha ao perceber obras que se parecem com cartazes ou outdoors, mas trazem mensagens claramente questionadoras e subversivas. É a lógica da publicidade utilizada para questionar sistemas de pensamento vigentes, como a dominação patriarcal, os sistemas de mercantilização da cultura e a incessante necessidade da critica como espetáculo.

No Brasil, o Coletivo Poro, de Minas Gerais, também utiliza as visualidades urbanas para instigar diálogos sobre o modo de consumir e habitar, cujo foco para esta pesquisa será a obra "Faixas de antissinalização" de 2009. Suas intervenções:

[...] são quase sempre efêmeras. Duram o tempo de uma panfletagem no centro da cidade ou o tempo de uma folha de ouro cair de uma árvore. Duram o tempo do deslocamento do ritmo cotidiano para um ritmo poético, questionador. É possível re-sensibilizar o espaço urbano? Uma intervenção pode durar o tempo em que a imagem-provocada ficar na memória de quem a viu. Ou o tempo enquanto as histórias de seus desbobramentos forem contadas. Quantas imagens uma intervenção pode gerar? (COLETIVO PORO, 2016) 
Em seu livro "Ações Poéticas do Poro" (2009), os artistas visuais Brígida Campbell e Marcelo Terça-Nada afirmam encontrarem políticas de intervenções nas insignificâncias da cidade. O fazem através da arte, mas também de pequenos gritos políticos.

Relatam que obras como as faixas de antissinalização que atacam as visualidades publicitárias, as folhas de árvore pintadas de ouro e dispostas pelos parques es cartazes da obra "Por outras práticas e espacialidades" - entre outras nos mais de catorze anos do coletivo - são porosidades no espaço urbano, feitas por muitos e por ninguém, direcionadas a todos e a ninguém.

De certa maneira, como relata Brasil $^{8}$ (2009), são obras que se baseiam em sua insignificância. Deslocamentos mínimos, sutilezas que, pela efemeridade, ficam no limite entre o ver e o não ver. Zonas temporárias dentro do mar de estímulos visuais que a urbe propõe. Alheias ao círculo de espetáculos e das instituições, esse tipo de ação - incitar a reflexão meio ao caos urbano - torna-se inadequada porque usa como territorialidade o cotidiano.

Os gestos ordinários circulam anonimamente, abaixo da mídia estridente. Citando uma parábola do teórico Giorgio Agamben, narra um rabino que certa vez disse que para instaurar o reino da paz, não era necessário destruir tudo e iniciar um novo mundo, mas deslocar apenas uma única coisa, um objeto, um arbusto, uma pedra - e assim proceder em relação a todas as outras coisas.

É sob essa ótica que operam iniciativas artísticas como as do Coletivo Poro. Profanam o espaço midiático porque utilizam sua estrutura e ótica para uma intervenção da desordem. A negligência da visão - onde todas as coisas estão dormentes aos olhos, nos afasta da percepção, que afasta da reflexão, que distrai a ação. Ocupar esses pequenos espaços - praças, outdoors, ruas, parques, essas zonas de convivência - é retomar uma política de usos. Utilizar a arte como uma estratégia da anti-disciplina do cotidiano.

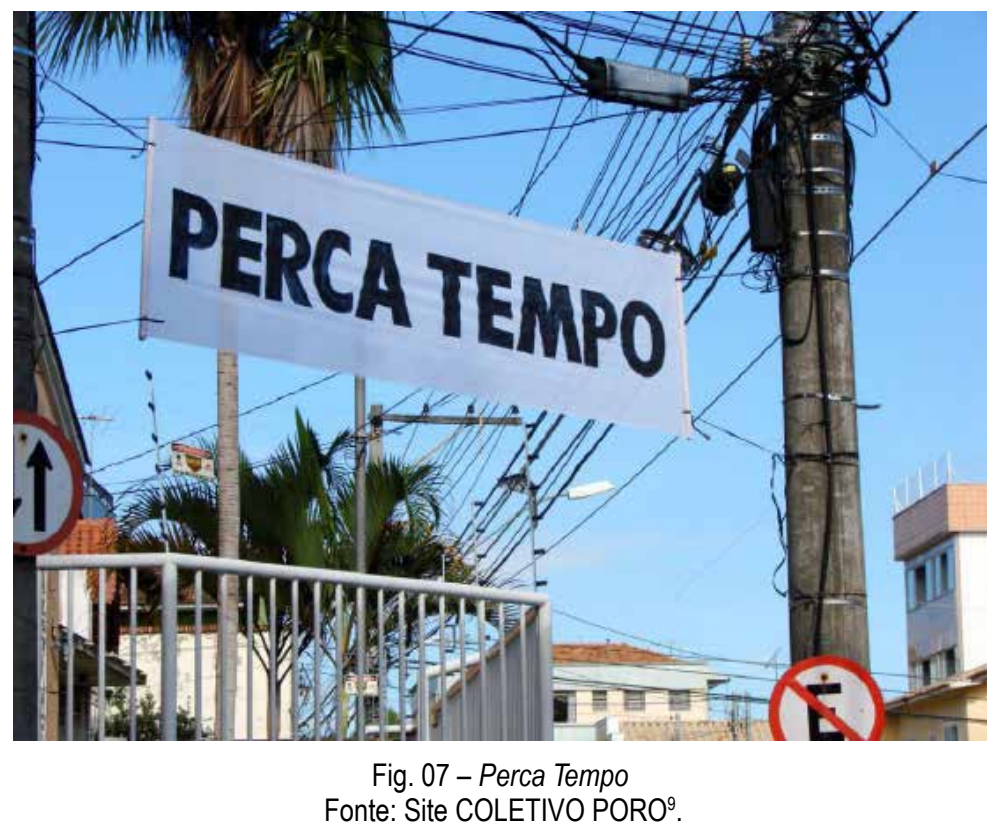

8 No mesmo livro do Coletivo, Ações Poéticas do Poro (2009).

9 Disponível em: http://poro.redezero.org/. Acessado em 16 de fevereiro de 2018. 
O que essas faixas possuem em comum com os outdoors citados? Entendem a arte como engajamento político. Brasil (2009) ainda aponta que esse tipo de obra artístico-política opera sobre dois domínios, do sentido e do sensível.

Do sentido porque não se trata do enunciado, mas do enunciável. Intervir nesses monumentos contemporâneos do consumo é contrapor os discursos de ordem que esses meios impõem, reinventando outros slogans e proposições de ordem. Não são do campo da comunicação persuasiva, mas atuam através dessa lógica.

Do sensível porque estabelece um limite sobre o que é e o que não é possível de ser dito, visto, afirmado, contrariado em certo momento histórico. Quando o artista intervém nesses espaços, automaticamente atua nos campos sensíveis da cidade porque desestabiliza o fluxo de discursos, interrompe - nem que por alguns segundos - a homogeneidade das narrativas.

A partir dessas microrresistências, a comunicação urbana pode ser reinventada, ressignificada e reproposta, pode tomar a forma de uma plataforma exibitiva da arte, ao mesmo tempo um vírus ao sistema e um convite a novos pontos de vista. O cotidiano, submetido ao domínio da comunicação persuasiva, ficará a deriva justamente pelo incômodo poético que a quebra oferece.

No embate entre a ordem publicitária e a desordem poética, o conhecimento sensível ofertado gratuitamente à população em outdoors, faixas de sinalização, ou em qualquer outro meio de massa, garante uma partilha pela cidade. Suspende a fala para propor o gesto. São diálogos do agora, que não prometem felicidades futuras. Suspendem o fluxo, como se dissessem: hoje, não. E nessa suspensão instauram a crise, íntima, sutil e silenciosa.

Da mesma forma que o Poro invade a visualidade urbana para contrapor algumas discussões pertinentes à população - controle, manipulação, paranoia, em um contexto local o Grupo ETC ${ }^{10}$ criou em 2014 uma ação urbana que logo movimentou Prefeitura, Polícia e fez com que o grupo fosse levado à delegacia para responder contra crime ambiental. Era o CIDADE À VENDA.

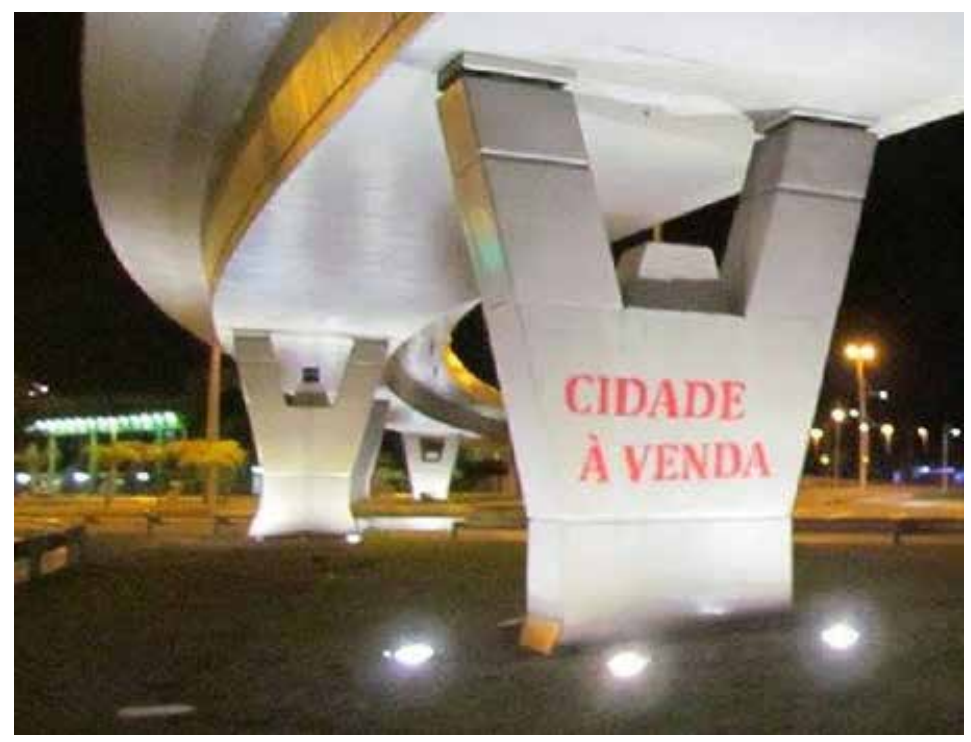

Fig. 08 - Cidade à Venda

Fonte: Dossiê Cidade à Venda, Grupo ETC ${ }^{11}$.

\footnotetext{
10 Composto por alunas do Centro de Artes da Universidade do Estado de Santa Catarina. O objetivo do grupo é usar ações diretas, em choque com as normas vigentes, com interferências nos fluxos cotidianos. 0 grupo afirma que propõe ruídos na "frequência contínua que visa domesticar e despolitizar a relação entre corpo e cidade, na busca de questionar e contaminar a sociedade do espetáculo" (COLETIVO PORO, pg. 2, 2014).
} 
Utilizando outro tipo de visibilidade outdoor, os muros da cidade, o ETC propõe uma intervenção a um espaço público, utilizando-o como publicidade temporária. É um classificado além dos espaços comerciais, um "vende-se esta cidade", porém em territórios que compõem ela mesma. A obra denuncia a política da espetacularização, proposta por Debord (1997), de utilizar a cidade como visualidade que inclui e exclui porque cria símbolos a partir dos modos de ver.

No contexto das anarquias experimentais pela arte, o muro é análogo ao outdoor publicitário porque, na simbologia visual, é um espaço em branco. Um dos poucos que ainda não foram conquistados pela lógica do marketing. Constitui um espaço a ser desbravado, e é ainda mais pirata porque é clandestino.

Utilizando a técnica do estêncil, transitavam pelas noites entre muros e viadutos de Florianópolis para incitar uma reflexão sobre a tomada da cidade pelos empreendimentos imobiliários e shoppings centers de luxo. Grafitavam CIDADE À VENDA.

De acordo com o Dossiê Cidade à Venda ${ }^{12}$, em janeiro de 2014, durante uma de suas saídas, quatro integrantes do coletivo foram interceptadas e levadas à delegacia por uma empresa de investigação. Foram sentenciadas, desse ocorrido, a fazer trabalho comunitário pela transgressão, que não foi considerada obra de arte pela gestão municipal.

Em reportagem do jornal Notícias do Dia (2014), a Secretaria de Comunicação da Prefeitura da Capital afirma que não considera a intervenção um ato artístico por conter cunho político e manifestação clara contra a gestão municipal. As pichações, segundo a secretaria, procuraram denegrir claramente a imagem do prefeito e da administração. No jogo discursivo da urbe, esse tipo de manifestação da arte ativista é repudiada porque representa uma brecha à crítica.

Olhando para a cidade, o ETC configura as visualidades em trânsito como seu lugar enquanto coletivo - enérgico, catártico e efêmero. Uma política em movimento, por isso em transição. Obra que se esvai do olhar do público, passante, cego. São bocas que se criam, e se extinguem entre um olhar e outro. Somem. Criam ambientes para outras convivências, outros tipos de movimentação, outros tipos de voz.

Contra atacando a panfletagem ideológica da retórica da venda, surge esse tipo de obra, fora do âmbito privado dos olhares, tendo nas mídias de grande formato seu espaço conquistado. Esse tipo de zona poética promove um atrito, estabelecido como parte da linguagem urbana porque as pessoas raramente percebem que o que está disposto é arte.

Para que continue surtindo o mesmo efeito, para que possam dar o mesmo susto, esse tipo de quebra de linguagem deverá ser sempre uma intervenção poética passageira. Sempre uma dúvida que passa pelos olhos, que se destaca, mas que se esvai. Sempre efêmera, autônoma, temporária. Sobre esse tipo de temporalidade nas poéticas urbanas, Hakim Bey ${ }^{13}$ chama de zona autônoma temporária.

Bey (2003) cunha diversos termos para retratar a arte política contemporânea. O autor discorre sobre uma sociedade que - ao tentar controlar inúmeros setores da vida humana, como o amor, a infância, a religião, a relação entre as pessoas, os

12 Material enviado ao autor por e-mail, em contato com a integrante Ana Castello.

13 Escritor, ensaísta, poeta e "anarquista ontológico", como define no primeiro capítulo de ser livro Caos - Terrorismo Poético e Outros Crimes Exemplares (2003). 
modos de ver, os mitos e, inclusive, a pornografia - cria ambientes impossíveis para $\mathrm{o}$ ato de conviver.

Afirma que o caos nunca morreu e que as correntes da Lei nunca foram quebradas porque, a priori, nunca realmente existiram - são criações, artefatos políticos humanos, propõe uma arte mais engajada em contrapor os incessantes estímulos da manutenção social.

Para ele, o ser humano deveria estar mais atento ao que ama e proporciona uma liberdade superior, ao passo que "todo o resto é mobília coberta, anestesia diária, merda para cérebros, tédio sub-réptil de regimes totalitários, censura banal e dor desnecessária" (BEY, 2003, p. 6).

Sobre o teor fantasioso das utopias contemporâneas - propostas com espetacular simbolismo para uma sociedade de massa que ruma cada vez mais à automação não apenas dos processos, mas dos sentidos - o autor polemiza:

\footnotetext{
Aqui estamos, engatinhando pelas frestas entre as paredes da Igreja, do Estado, da Escola e da Empresa, todos os monólitos paranoicos. Arrancados da tribo pela nostalgia selvagem, escavamos em busca de mundos perdidos, bombas imaginárias. [...] Se eu fosse beijar você aqui, chamariam isso de um ato de terrorismo - então vamos levar nossos revólveres para a cama e acordar a cidade à meia-noite como bandidos bêbados celebrando a mensagem do sabor do caos com um tiroteio. (BEY, 2003, p. 6)
}

Para Bey, a única forma de a arte desvencilhar-se também do sistema institucional - que assassina a própria liberdade da arte - é assumir-se uma ferramenta de contraterrorismo.

Vivendo abaixo das mãos controladoras das políticas religiosas, das condutas públicas, do ensino opressor e raso, e das necessidades simbólicas criadas pela indústria, é impossível que o cidadão diga-se livre.

A panfletagem ideológica criada e assumida pela publicidade seduz com suas imagens de extrema juventude e beleza, quase como feitiçaria, que cria ao redor de si um espaço físico/psíquico de metamorfose do cotidiano num lugar genérico e angelical.

O feiticeiro, porém, proclama-se um dos autênticos realistas. Mancha o mundo real e a consciência com luzes, formas, cores e texto. Uma forma de contrapor a produção discursiva dos anúncios, das chamadas, dos slogans, dos teasers, dos outdoors - a poesia como ato terrorista.

Enquanto os feiticeiros do marketing, os bruxos do recreio e das listas de chamada, os magos das leis e condutas e os xamãs religiosos dispostos em altares procurarem deter o fluxo do pensamento e das relações reais, possíveis em qualquer sociedade consciente de seu próprio esquema de pensamento, essa ordem de poder considerará ameaçadora todo tipo de informação que fugir do raio válido dentro de sua teia de verdades. Na urbe contemporânea, meio aos estímulos da propaganda e da publicidade, a contra feitiçaria é inimiga porque ameaça o poder das charadas e promove a resistência dessas teias ilusórias.

Hakim Bey (2003) propõe então uma arte-sabotagem. Um propósito artístico de lutar em favor do pensamento autônomo, da livre escolha e da anticensura. A arte-sabotagem pretende ser um exemplo e, ao mesmo tempo, um choque estético que não contempla as linguagens do consumo propriamente ditas. 
É uma proposta de fazer ações como metáforas, criações por meio de destruições do que se discute. Uma Cruzada Estética que ataca, principalmente, as obras individuais e a própria arte insípida das galerias. Conforme afirma o autor, "a arte-sabotagem procura causar danos às instituições que usam a arte para diminuir a consciência e lucrar com a ilusão" (BEY, 2003, p. 11).

Em sua teoria, o artista propõe uma série de atos considerados, na sua visão, terrorismos poéticos. Atentando-se ao fato de que os terroristas-poéticos negam a sedução praticada e a busca pela satisfação passageira e bela, ainda afirma que se comportam como "um trapaceiro totalmente confiante cujo objetivo não é dinheiro, mas a transformação" (BEY, 2003, p. 7).

Bey ainda sugere que $\mathrm{o}$ artista interessado em disseminar terrorismos poéticos não deve fazer arte para ser apreciada por outros artistas e fundamentalistas da crítica de arte especializada, mas para aquelas pessoas que não perceberão que aquilo que você fez é arte. Em meio à lista de proposições artísticas, Bey (2003) discorre que pode-se assumir uma série de performances como dançar de forma bizarra durante a noite inteira nos caixas eletrônicos dos bancos, espalhar peças de argila que sugiram artefatos alienígenas em parques estaduais, sequestrar alguém com o intuito de fazê-lo feliz, escolher alguém ao acaso e fazê-lo acreditar que você é herdeiro de uma fortuna enorme e inútil, como cinco mil quilômetros na Antártida, rabiscar poemas nos lavabos dos tribunais, colocar slogans com letras gigantes nos muros dos playgrounds, entre tantos outros.

Não importa - qualquer que seja o ato, ele deve fazer com que o público reaja de forma tão forte quanto ao terror. Seja uma profunda repugnância pelo ato, uma tensão sexual momentânea, um temor supersticioso, uma súbita revelação intuitiva ou uma angústia dadaísta - se o terrorismo não adentrar a vida de alguém naquele determinado minuto (além da vida do artista), ele falhou.

Ainda sobre esse tipo de manifestação artística, Bey (2003) afirma que o TP14 é um ato livre no verdadeiro teatro de crueldades simbólicas que a contemporaneidade propõe como realidade diária. Ele conclui:

[...] o TP deve afastar-se de forma categórica de todas as estruturas tradicionais para o consumo de arte [...] Uma primorosa sedução praticada não apenas em busca da satisfação mútua, mas também como um ato consciente de uma vida deliberadamente bela [...] Abraçar a desordem como fonte de estilo e como armazém de volúpia, um fundamento de nossa civilização alienígena e oculta, nossa estética conspiratória, nossa espionagem lunática - essa é a ação (reconheçamos) de um certo tipo de artista ou de uma criança de 10 ou 13 anos [...] nós e eles, os selvagens, somos o espelho um do outro, unidos e limitados por aquele cordão de prata que define as fronteiras entre a sensualidade, a transgressão e a revelação [...] Se certos museus e galerias merecem, de vez em quando, receber uma tijolada pela janela - não a destruição, mas sim uma sacudida na sua complacência -, então o que dizer dos BANCOS? Galerias transformam beleza em mercadoria, mas os bancos transmutam a Imaginação em vezes de dívida. (BEY, 2003, p. 7-12)

A abordagem do autor sobre esse tipo de manifestação artística como forma de propor zonas poéticas mediante a apropriação de zonas autônomas, no caso da pesquisa o outdoor, revela zonas públicas de capital privado que expõem o pensamento vigente do consumo.

14 Forma como o autor cunha o Terrorismo Poético (TP). 
Se, conforme ele, "a civilização é dona de todas as locações e da maioria das armas" (BEY, 2003, p. 19), proponho o olhar para desvios poéticos que ajam como feitiço, não no sentido de serem mera metáfora para a literatura, mas símbolos que provoquem epifanias particulares.

Motes que absorvam o estilo discursivo, mas neguem o próprio cerne do ato da publicidade: o mundo dos artefatos criado pelas mãos do homem, pequenas odes ao caos da cidade, provocações efêmeras que, assim como as mensagens do assentamento da cultura de massa, desaparecerão ao propósito da própria mídia na qual estão inseridas. Buscam novos territórios, novas plataformas exibitivas da arte que contesta enquanto sensibiliza, tornando esse tipo específico de manifestação artística um exemplo da retomada dos lugares para a retomada do pertencimento.

\subsection{Ambientes urbanos: pelo desbravamento dos espaços sensíveis}

Afirma-se então que a publicidade perpetua a cultura da imagem: molda aspectos do ser e do parecer enviesados por hábitos de consumo que se fantasiam de hábitos instransponíveis ao conviver urbano. Para autores que abordam a questão das ambiências, como Jean-Paul Thibaud (2012) e João Soares Pena e Osnildo Adão Wan-Dall Junior (2012), o fato da desconstrução do sentimento de pertencimento local em detrimento ao sentimento global pode ter um de seus pilares na fundamentação dos territórios.

Como Pena e Junior (p. 47, 2012) abordam, "o espaço público é, fundamentalmente, lugar de conflito e dissenso [...] do mesmo modo, há inúmeras tentativas de expropriação desse caráter dos espaços públicos na cidade contemporânea". Assim, tomando como natural o conflito a partir da convivência urbana, restaria à cidade o controle dessas disputas em um contexto benéfico à população.

Se for responsabilidade do planejamento urbano a disposição de áreas de convivência e possibilidade de discurso, também seria de responsabilidade dessa mesma área o planejamento de zonas de reapropriação desse discurso. Na lógica do mercado, porém, o investimento na consciência e na retomada do discurso social é algo perigoso e, por que não, aparentemente utópico.

Os autores ainda abordam o pensamento de Paola Berenstein Jacques (2009) sobre a necessidade de uma mudança na narrativa da análise dos conflitos. Afirmam, então, pela inferência da autora, que "os atuais projetos urbanos contemporâneos são realizados no mundo inteiro segundo uma mesma "estratégia": homogeneizadora, espetacular e consensual". Para Jacques, os projetos urbanos buscam transformar a cidade em um cenário de espaços desencarnados, fachadas sem corpo, pura imagem de propaganda.

Para Thibaud, o novo desafio seria de instalar atmosferas urbanas que, se não desintegrariam conflitos, moldariam de forma mais eficiente as convivências pela fabricação de espaços sensíveis. Isso significa criar condições para uma cidade que seja habitável para todos, em condições de bem-estar social e de boa convivência.

Essa ambientação, ou o estudo da ambiência, seria representado por todas as peças visuais e sensoriais que compõem a cidade. Dessa forma, desde escritas impregnadas na urbe como placas, lojas, marcas e propaganda, até o próprio jeito de 
dispor de espaços de convivência, passando pelo aspecto arquitetônico da cidade (caso abordemos o pertencimento cultural), propõem imagens que, essencialmente, remetem ao colonialismo publicitário.

As escritas urbanas da publicidade mostram uma cidade pouco plural, mas que possui impregnado em seu imaginário um apego ao consumo. É perceptível que existe, além de um imaginário local - uma sensação de pertencimento a outra lógica cultural, a cultura do consumo. Produz-se uma nova identidade individual e, ao mesmo tempo coletiva, um tipo de comunidade imaginada aparentemente indestrutível do ponto de vista capitalista, a comunidade consumidora.

Ambientar um espaço é, portanto, trabalhar seus valores afetivos. Em termos propriamente urbanos, isso nos leva a interrogar sobre os tipos de tonalidades afetivas emprestadas aos espaços urbanos. A cidade contemporânea parece atravessada por um duplo movimento de programação do festivo e de integração da segurança por um amplo espectro que vai desde uma "ecologia do medo", à "ecologia do consumo", até a "ecologia de encantamento".

Pode-se constatar que o discurso torna-se uma verdadeira dimensão da governança urbana, uma vez que se trata de ferramentas persuasivas dispostas a instituir algo comum num mundo compartilhado.

Guy Debord (1997) também aborda o tema do urbanismo em seu "Sociedade do Espetáculo". Para o autor, o urbanismo é a tomada de posse do ambiente natural e humano pelo ambiente capitalista, pois ao desenvolver sua lógica interna baseada na dominação absoluta, refaz as configurações do espaço com um cenário criado e produzido para seus próprios interesses.

Falando-se do espetáculo, a cidade é palco construído do próprio show que proporciona para seus habitantes. Nesse domínio, o outdoor também é questão urbana e participa dos planejamentos de urbanização, pois infere diretamente sobre a atmosfera da cidade, atuando em suas visualidades.

Urbanizar, para Debord, necessariamente significa separar. A lógica da economia capitalista é a separação do individuo em detrimento da unificação do ser. Desta forma, urbanizar significaria na visão debordeana fazer a manutenção da permanente tarefa de separar o poder das classes e, na lógica do consumo, esse fato torna-se ainda mais escancarado e intrusivo. Na lógica do marketing, pertence quem possui poder de compra. Exclui-se desse processo, então, toda e qualquer pessoa cujas possiblidades do ato da compra estejam suspensas.

A construção de um discurso aparentemente acolhedor, mas tendo em seu cerne uma ótica exclusiva, é fundamental para manter-se ordem na cidade contemporânea.

Se desde a Revolução Francesa um dos esforços dos mantedores do poder é a supressão da rua como meio de manter a ordem, é no discurso publicitário que mesmo na rua - distrai-se o indivíduo. Na coletividade dos centros urbanos, a ótica do consumo funciona ao mesmo tempo como combustível e isolamento, pois o ser consumidor planeja suas ações mediante seu poder de compra.

Combustível no sentido de perpetuar o esquema de trabalhar para comprar artefatos que nos façam ter que trabalhar ainda mais para comprar mais artefatos semelhantes ou para adquirir melhorias dos artefatos já possuídos. 
Isolamento no sentido de que a ótica publicitária não comporta, a priori, grandes ações coletivas - o trabalho e a ação são sempre produzidos, em um primeiro momento, a sós.

\subsection{Zonas autônomas temporárias e terrorismos poéticos: propostas para exibições piratas}

Estamos nós, que vivemos no presente, condenados a nunca experimentar a autonomia, nunca pisarmos, nem que seja por um momento sequer, num pedaço de terra governado apenas pela liberdade? Estamos reduzidos a sentir nostalgia pelo passado, ou pelo futuro? Devemos esperar até que o mundo inteiro esteja livre do controle político para que pelo menos um de nós possa afirmar que sabe o que é ser livre? Tanto a lógica quanto a emoção condenam tal suposição. A razão diz que o indivíduo não pode lutar por aquilo que não conhece. E o coração revolta-se diante de um universo tão cruel a ponto de cometer tais injustiças justamente com a nossa, dentre todas as gerações da humanidade. (BEY, 2003, p. 4)

Hakim Bey (s/d) formula em seu "TAZ - Zona Autônoma Temporária" um conceito de territorialização efêmera de espaços a serem ocupados para fins de tomada de discurso. Ao assumir esse conceito como uma fantasia poética, o autor compara-a com a história da pirataria e admite a necessidade de rebelar-se.

Essa rebelião tem como objetivo não a mudança de uma consciência, mas a mudança o mundo. Flertando com a utopia, concebe-se a Zona Autônoma Temporária como um levante - no sentido histórico dessa concepção - porém temporário, uma experiência de pico se comparada aos parâmetros sociais da consciência e experiência normativa.

Conceitua-se levante a partir da perspectiva das trajetórias sociais. Se o status quo é o próprio tempo presente, um levante é um movimento acima e além do tempo. Se o Estado é a própria História presente, o levante é a negação da ação em função da dialética do presente. Seja dançar sobre um poste ou escapar por uma fresta, um levante é a conquista de uma "permanência temporária". Da mesma maneira que a conquista do espaço elitista das mensagens publicitárias.

Do mesmo modo que uma provocação em grande escala - nove metros de largura, três de altura - pode ser uma investida, um contra ataque de permanência temporária, um levante.

Portanto, a TAZ comporta-se como uma operação de guerrilha que libera uma área (seja ela espacial, temporal ou imaginária) e se dissipa antes mesmo de chegar à discussão do Estado. A Zona Autônoma Temporária, nesse sentido, serve mais para mudar estados que para mudar Estados.

Sobre suas especificações, é autônoma porque não depende (nem poderia depender) de iniciativas públicas para sua concepção. É parte de uma ideologia do contrafluxo. É um ataque perpétuo ao pensamento vigente, mas nunca violento. A própria ideologia das zonas temporárias é de atacar as estruturas de controle por viés do pensamento.

O primeiro e mais fundamental passo para a TAZ é o simples ato da percepção, negada por iniciativas políticas coletivas que barram a evolução das narrativas presentes. Trabalhar pelo pensamento dessas zonas é investigar maneiras de agir, modos de ser notado pela manipulação do discurso. 
E é temporária por ter no seu cerne a tática do "ataque e fuja" (BEY, 2003, p. 6). Deve aparecer e desaparecer antes mesmo de poder ser percebida pelo sistema. Deve dissolver-se e refazer-se em outro lugar antes de ser institucionalizada pelo Estado. A TAZ é um microcosmo do sonho de liberdade, uma tática babilônica de ataque e, ao mesmo tempo, defesa. "[...] é uma tática perfeita para uma época em que o Estado é onipresente e todo-poderoso mas, ao mesmo tempo, repleto de rachaduras e fendas" (BEY, 2003, p. 6).

Num mundo já conquistado até seu último pedaço de terra, a necessidade de rebelar-se pode brotar de locais mais remotos onde a vida cotidiana encontra espaços para respiros filosóficos. Não há um mapa certo para o aparecimento de zonas autônomas, elas devem surgir sob irrupções temporárias. Conforme descreve Bey:

O último pedaço da Terra não reivindicado por uma nação-Estado foi devorado em 1899. O nosso século é o primeiro sem terra incógnita, sem fronteiras. Nacionalidade é o princípio mais importante do conceito de "governo" - nenhuma ponta de rocha no Mar do Sul pode ficar em aberto, nem um vale remoto, sequer a lua ou os planetas. Essa é a apoteose do "gangsterismo territorial". Nenhum centímetro quadrado da Terra está livre da polícia ou dos impostos... em teoria [...] Dentro das complexidades fractais da geografia atual, o mapa pode detectar apenas malhas dimensionais. Imensidões embutidas e escondidas escapam da fita métrica. $\mathrm{O}$ mapa não é exato, o mapa não pode ser exato. [...] O mapa está fechado, mas a zona autônoma está aberta. Metaforicamente, ela se desdobra por dentro das dimensões fractais invisíveis à cartografia do Controle. E aqui podemos apresentar o conceito de psicotopologia (e psicotopografia) como uma "ciência" alternativa àquela da pesquisa e criação de mapas e "imperialismo psíquico" do Estado. [...] Estamos à procura de "espaços" (geográficos, sociais, culturais, imaginários) com potencial de florescer como zonas autônomas [...]. (BEY, 2003, p. 8-9)

No pensamento do autor, zonas fora do alcance da cartografia urbana são zonas autônomas em potencial. De jantares surpresa a conclaves de eco-sabotadores, conferências anarquistas a festas gay, de clubes noturnos que funcionam em prédios a piqueniques libertários - todos esses eventos flertam com as TAZ. Sejam eventos para poucos amigos ou carnavais de rua, a espontaneidade dessas ocasiões deve provocar um sentimento de mudança paradigmática.

Admitindo que a mídia faz convites esporádicos para celebrações da vida. Bey (s/d) inclusive critica o sistema de feriados, afirmando que são liberdades pré-programadas em função da manutenção de um estado de dormência. Afirma-se que as zonas autônomas são respostas da emergência de uma cultura festiva e, para isso, pode e deve utilizar os meios de comunicação à disposição para propor maneiras de estar junto. Ou de pensar junto.

Essa necessidade de pertencer faz alusão direta ao sistema de convivência que estabelecemos como grupo social. Da possibilidade de uma visão de mundo pós-ideológica e multifacetada que a contemporaneidade alcança, vive-se ao mesmo tempo um momento de velocidades e fetichismos, onde a mercadoria e seus mecanismos criam unidades que vendem uma verdade pavimentada que ofusca a diversidade cultural e a individualidade dos centros urbanos. 


\section{Conclusão}

$\mathrm{Na}$ contemporaneidade, todo lugar é igual ao outro. Esse fenômeno, na visão de Bey (s/d), cria nômades urbanos - ciganos, viajantes psíquicos - desligados de qualquer lugar ou tempo em busca da espetacularização da vida. Esse perfil, por fim, engloba todos nós que vivemos para abastecermos nossos automóveis, que pulamos de férias em férias, que viajamos pela Internet, que trocamos de emprego para mudarmos nossa qualidade de vida, que buscamos novos produtos para incorporarmos em nossas novas dietas.

A partir das obras analisadas, nota-se a construção de zonas temporárias que reestabeleçam espaços de discussão mediados por meios de comunicação de massa. Dessa tentativa, Bey (2003) provoca:

\footnotetext{
Abra um mapa do território; sobre ele, coloque um mapa das mudanças políticas; sobre ele, ponha um mapa da internet, especialmente da contra-net, com sua ênfase no fluxo clandestino de informações e logística; e, por último, sobre tudo isso, o mapa 1:1 da imaginação criativa, estética, valores. A malha resultante ganha vida, animada por inesperados redemoinhos e explosões de energia, coagulações de luz, túneis secretos, surpresas. (BEY, 2003, p. 11)
}

O papel fundamental dessas zonas propostas a partir dos outdoors é sugerir diretamente um contra pensamento ao conceito de comunicação para meios publicitários. É um agente infiltrado no sistema, trabalhando para o outro lado da fronteira. Nesses espaços-entre que a publicidade constrói, situado no futuro e nunca no presente, instauro uma indagação. Nesse fenômeno, o artista torna-se um publicitário, mas no contra fluxo. Um terrorista poético, efêmero. Um ativista de geografias temporárias.

Seja na intimidade do lar, ou pelas ruas e avenidas dos centros urbanos, o sistema intricado de meios de comunicação de massa tecem uma teia de persuasões que substituem o sentido da coletividade pela ascensão do indivíduo. Como afirma Berger (1999), o jogo traçado pela publicidade - o sistema comunicacional das nações capitalistas - envolve o embate entre a vida real e a projeção futura dessa vida, melhorada pelos produtos criados pelo trabalho humano.

Afirmar isso também é afirmar que, na contemporaneidade, há um caráter de objeto nas relações afetivas. Se sonhar é sinônimo de ter, e ter é sinônimo de ser, logo o ser social pauta sua vida mediante seus discursos normativos de consumo. Como ainda pontua Berger (1999), ter dinheiro é ter direito à vida. Não no sentido do labor, onde se compra para não morrer de fome ou frio, mas vida no sentido simbólico do termo. Poder gastar dinheiro é poder viver porque, de acordo com as legendas publicitárias, aqueles que não possuem poder de compra tornam-se anônimos. As zonas autônomas temporárias, nesse sentido, subvertem a rede de mensagens e propõem outras formas de pertencimento, piratas.

Nesse contexto, a cidade é palco da verbalização da aparência, daquilo que é extrassensível. Seja dentro dos lares pelas telas, rótulos, embalagens e etiquetas; seja no espaço público com seus letreiros, outdoors, vitrines, muros, casas - habitar o espaço urbano é deixar-se mediado pelo espetáculo construído pela cultura da publicidade. 
Como cultura, admite-se o pensamento de Stuart Hall (1997) quando afirma que se trata de um sistema de significados compartilhados. Tornando o trabalho o modo aquisitivo dos objetos, e os objetos o modo aquisitivo da felicidade, esse sistema sígnico criado pela indústria, pelo capital e pela publicidade tornam o consumo uma prática diária e constante. Por isso, vive quem consome.

Partindo do problema de pesquisa, perguntava-se como pode a arte contemporânea possibilitar um contra-ataque dos discursos normativos propondo a ocupação de outdoors como plataforma exibitiva de conceitos piratas?

Compreendendo esse espaço como um sistema de signos oriundos do tempo contemporâneo, questionou-se como se comportam as produções artísticas que dialogam os conceitos desse regime imposto para a sociedade hiperconsumidora, principalmente como constituem o outdoor como uma zona autônoma temporária que dialoga contradiscursos a partir da ótica dos terrorismos poéticos. Problematizaram-se, então, as linguagens poéticas a partir da discussão sobre as políticas sociais e afetivas propostas pela publicidade. Para tanto, analisou-se as obras de quatro artistas: o mexicano Félix Gonzáles-Torres, a americana Barbara Kruger, o coletivo mineiro Poro e o coletivo catarinense ETC.

$\mathrm{Na}$ definição desse trabalho, o outdoor configura uma zona autônoma temporária, como afirma Bey (s/d), pois é uma territorialização espacial que pode ser ocupada para a (re)tomada do discurso. Ao utilizar o próprio meio de comunicação para contra-atacar sua própria retórica, assume-se a obra como uma fantasia poética cujo objetivo é mudar uma consciência, um pensamento vigente. Os outdoors analisados tornam-se então vândalos do sistema, terrorismos poéticos, ainda na visão de Bey (2003).

Assim, analisando o objetivo geral da pesquisa, correlacionar o outdoor como veículo midiático e ferramenta da retórica capitalista e sua ocupação como plataforma exibitiva da arte e de seus discursos piratas, afirma-se que mediante essa (re) tomada do discurso, o outdoor como zona autônoma temporária a serviço da poesia terrorista comprova que essa realidade é passível de questionamentos pela arte urbana, como fizeram os outdoors íntimos de Félix Gonzalez-Torres, as linguagens publicitário-poéticas de Barbara Kruger, as dessinalizações do Coletivo Poro e as provocações a uma cidade à venda do Grupo ETC. Esse espaço intocável, o espaço da publicidade, mostra-se também passível de brechas pela lógica do capital. Sob a ótica de pagar para criticar, tornam-se alvo pela sua própria permissividade.

Mediante o trabalho, percebeu-se a importância acerca da compreensão de todas as imagens que nos cercam e de seus propósitos. Tomados por múltiplos estímulos, nota-se que a cultura contemporânea molda-se na velocidade da cultura da hiperinformação, se esvai da mesma forma que surge. Esses flashes persuasivos fazem com que se acostume o olhar para seus convites, suas seduções.

Se tudo que existe no mundo emana significado, exige cuidado de leitura, certamente as mensagens publicitárias demandam do consumidor uma atenção especial, porque seduzem mediante a poetização do cotidiano, muda-se a sensação de estar vivo, muda o tempo da vida e o tempo da ação. 
Como afirma Debord (2003), a sociedade atual muda seu tempo interno porque inverte os valores necessários para a continuidade do sistema. Apenas o tempo espetacular é consumível. Consumimos esse tempo do espetáculo porque ele é dividido em negociações possíveis.Nada é eterno na cultura do capital, nem poderia ser. Esse novo tempo cíclico e pessoal é a força matriz do consumo como promoção da vida, e da vida como espetáculo urbano. Não é o tempo da vivência, mas o tempo do glamour.

Por isso a arte outdoor constitui espaços-entre, configuram-se como tempos-entre, porque devolvem aos olhos o que o excesso desgasta. Convidam novos terroristas poéticos porque se mostram possíveis. Buscam novos desbravadores de zonas temporárias porque desaparecem assim que fazem sentido. São polêmicos tanto quanto efêmeros, e constituem uma poética possível ao espaço urbanizado da cidade, uma tentativa de voz em meio ao excesso de vozes.

\section{Referências}

BEY, Hakim. Caos: terrorismo poético e outros crimes exemplares. São Paulo: Conrad Editora do Brasil, 2003.

BEY, Hakim. TAZ: Zona Autônoma Temporária. São Paulo: Conrad, 2003.

BRASIL, André. Insignificâncias: a política nas intervenções do Poro. 2009. In: CAMPBELL, Brígida, TERÇA-NADA, Marcelo. Ações políticas do Poro. São Paulo: Radical Livros, 2011.

COLETIVO PORO. Acessado em 16 de fevereiro de 2018. Disponível em: http://poro. redezero.org/

DEBORD, Guy. A sociedade do espetáculo. Rio de Janeiro: Contraponto, 2003.

HALL, Stuart. The work of representation. In: Representation - Cultural representations and signifying practices. Londres: SAGE, 1997.

JACQUES, Paola Berenstein. Notas sobre espaço público e imagens da cidade. 2009. Acessado em 15 de fevereiro de 2018. Disponível em: http://www.vitruvius.com.br/ revistas/read/arquitextos/10.110/41l.

LUCIE-SMITH, Edward. Os Movimentos Artísticos a partir de 1945. São Paulo: Martins Fontes, 2006. 
NOTÍCIAS DO DIA. 2014. Grupo responde por crime ambiental após espalhar a mensagem "Cidade à Venda" pela capital. Acessado em 16 de fevereiro de 2018. Disponível em: http://ndonline.com.br/florianopolis/noticias/162767-arte-ou-pichacao.html.

OBRIST, Hans Ulrich. Entrevistas: volume 4. Rio de Janeiro: Cobogó, 2011.

PENA, João Soares. JUNIOR, Osnildo Adão Wan-Dall. Partilha e conflito no espaço público: experiências urbanas na cidade de Salvador. Revista Redobra. Universidade Federal da Bahia: 2012. Acessado em 15 de fevereiro de 2018. Disponível em: http:// www.redobra.ufba.br/wp-content/uploads/2012/04/redobra9_Partilha-e-conflito-no-espaco-publico.pdf.

SILVA, Vanessa R. de L. Os Caminhos Entre a Arte e a Publicidade: da produção do discurso à construção do sentido - uma leitura das obras de Oliviero Toscani e Bárbara Kruger. Revista Espcom, Belo Horizonte,№1, 2006.

THIBAUD, Jean-Paul. O devir ambiente do mundo urbano. Revista Redobra. Universidade Federal da Bahia: 2012. Acessado em 17 de fevereiro de 2018. Disponível em: http://www.redobra.ufba.br/wp-content/uploads/2012/04/redobra9_O-devir-ambiente-do-mundo-urbano.pdf.

TOSCANI, O. A publicidade é um cadáver que nos sorri. Rio de Janeiro: Ediouro, 2005.

WALLESTON, Aimee. "Marlene McCartys Resilient Fury". In: Art in America Magazine. Acessado em 15/02/2018. Disponível em: https://www.artinamericamagazine.com/ news-features/news/marlene-mccarty/. 